\title{
Practice-oriented Approach in Teaching BIM technologies to Senior Students of Civil Engineering Universities
}

\author{
Aleksandra Masyonene [0000-0001-7811-3855]
}

Peter the Great St.Petersburg Polytechnic University, St. Petersburg, Russia masyonene.ar@gmail.com

\begin{abstract}
The article discusses the use of a project-based interdisciplinary practice-oriented approach in the implementation of BIM technologies in the educational process for senior students of architectural and civil engineering universities. At the initial stage of the educational process, BIM technologies are introducing by supplementing the relevant sections in the existing courses. When teaching senior students, it is proposing to organize interdisciplinary student teams to solve cases based on real problems on a competitive basis. The demand for the implementation of information design technologies in the construction industry is steadily growing, thanks to the competitive advantages gained by the player in the construction market when introducing BIM technologies, however, the complexity of training specialists across the entire spectrum of functional capabilities. The use of this technology prevents the active transition of players in the construction market to the full use of building information modeling technologies, which confirms the relevance of the chosen topic. The article also examines the shortcomings of the existing education system. The method proposed by the author is not traditional in the educational system and requires a review of the existing educational tradition in technical universities.
\end{abstract}

Keywords: Information Technologies, Building Information Modeling, BIM, Higher Education, Digital Twins, Educational Process.

\section{Introduction}

Despite the active introduction in the educational process of architectural and construction universities of disciplines introducing students to the tools of BIM-design technology, at the moment, the insufficiency (superficiality) of this approach is beginning to become more pronounced for obtaining specialists in the construction industry that are in demand on the labor market.

The advantages of implementing BIM technology in the design and operation of construction projects are more and more obvious for specialists in the construction industry; however, the complexity of training specialists across the entire spectrum of the

Copyright c 2020 for this paper by its authors. Use permitted under Creative Commons License Attribution 4.0 International (CC BY 4.0). 


\section{A. Masyonene}

functionality of this technology prevents the active transition of players in the construction market. With the full use of information technology design, which hinders the overall development of the construction industry in the Russian Federation [1].

However, the demand for the implementation of information design technology in the construction industry is growing steadily due to the acquired competitive advantages in the implementation of BIM technologies, which confirms the relevance of the chosen topic [2].

The most obvious shortcomings of the current education system for engineering and construction specialties at universities include:

- More often graduates have no practical experience in real projects;

- Obsolescence of the material and technical base and software used;

- The quality of graduate training does not meet the needs of employers

- The complexity of updating educational programs;

- The need for continuous updating of teachers' knowledge in connection with the exponential development of technology [3].

The rating of any university directly depends on the theoretical and practical competencies of its graduates entering the labor market, as well as the compliance of the quality of their training with modern and promising professional requirements [4].

Let us consider in more detail what tasks solved by BIM technology made its implementation an urgent task for higher education. Here are just a few of them:

- The ability to create a conceptual model of a construction object;

- Variability in design;

- The possibility of obtaining a feasibility study of the future facility;

- Calculation of the possibility of compaction of existing buildings through the integration of projected construction objects;

- Realistic presentation of the construction object to the customer;

- Improving the quality of design work, reducing errors (collisions) associated with the "human factor"

- Reduction of design time;

- Filling the design model of the object with information (information model);

- Joint work on one model of units with different locations

- Better consistency of sections of the project

- Fast receipt of sets of working documentation;

- No duplicate data;

- Convenient planning of construction materials production and logistics;

- Operational interaction and author's control at the construction site;

- Preparation of a project for a construction organization based on an information model;

- Receipt of the schedule (calendar and network) of work production (4D)

- Estimated construction cost (5D)

- Convenient tracking of the quality and dynamics of construction and installation work at the construction site 
- Operational control of deviations and correction of defects;

- Obtaining the necessary information about the construction object from the information model;

- Always up-to-date information about the construction object at all stages of its life cycle;

- Transfer of information about the object to building management systems.

In this regard, to increase it, it is necessary to introduce practice-oriented interdisciplinary teaching methods based on the development of projects of real objects into the educational process.

In work [5], it was emphasizing that in the training of specialists it is necessary to identify areas that correspond to modern requirements:

- Interdisciplinary knowledge and the ability to interdisciplinary justification of design decisions,

- The ability to think systematically and independently,

- Identify and effectively solve production problems using competencies mastered at the university,

- Focus on performance in professional activities.

\section{Methods}

For a better understanding of the information modeling process. As well as the principles of joint work on a project, it is necessary to create interdisciplinary student groups formed similar to the organizational structure of design organizations, including an architect-designer, a designer, related specialists, where each student can develop a separate section of the project or combine different roles, for example: architect, designer, engineer.

The teacher in such a group is assigned the role of the chief engineer and (or) the architect of the project [6].

\section{$3 \quad$ Results}

The logic of introducing this technique into the educational process of the university presented in Table 1. 
Table 1. The introduction of BIM technologies into the educational process.

\begin{tabular}{|c|c|c|}
\hline $\begin{array}{l}\text { Year of } \\
\text { study }\end{array}$ & Learning model & Goals and objectives \\
\hline 1 & $\begin{array}{l}\text { In the main educational process by disci- } \\
\text { pline }\end{array}$ & $\begin{array}{l}\text { The student uses IT with confi- } \\
\text { dence. } \\
\text { Mastering the basic set of soft- } \\
\text { ware. }\end{array}$ \\
\hline $2-3$ & $\begin{array}{l}\text { In the main educational process in the dis- } \\
\text { ciplines of information and graphic design } \\
\text { Seminars, participation in specialized } \\
\text { competitions }\end{array}$ & $\begin{array}{l}\text { Student user of specialized soft- } \\
\text { ware for solving architectural, de- } \\
\text { sign, engineering and other tasks. } \\
\text { Mastering the basic tools of BIM } \\
\text { technology in accordance with the } \\
\text { studied disciplines. }\end{array}$ \\
\hline $4-5$ & $\begin{array}{l}\text { In the main educational process in the dis- } \\
\text { ciplines of information and graphic design } \\
\text { Seminars, participation in specialized } \\
\text { competitions } \\
\text { Team works }\end{array}$ & $\begin{array}{l}\text { Training to work in an interdisci- } \\
\text { plinary team. } \\
\text { Solving real problems ( cases). } \\
\text { Defense of a group final qualify- } \\
\text { ing work based on the developed } \\
\text { case. }\end{array}$ \\
\hline
\end{tabular}

\section{Discussion}

In the process of joint work, it proposed to develop real tasks (cases) of interested players in the construction industry. Thus, using cloud technologies and collaboration methods, students will learn in practice to develop information models of buildings in a group project, fill models with attributes and get the information necessary for creating a project from the model, regardless of the location of the faculty or a particular student. One example of the introduction of BIM technology in the educational process of St. Petersburg State University of Architecture and Civil Engineering is a joint project of St. Petersburg State University of Architecture and Civil Engineering and Saimaa University of Applied Sciences (Finland). "BIMICE - Integration of BIM in Higher and Professional Education" (BIM-ICE - BIM Integration in Higher and Continuing Education), he aim of which is "to increase the level of knowledge of students and the professional community in the field of BIM technologies. To improve the quality of professional education that guarantees the training of highly qualified personnel for the activities of the construction industry" [7].

A similar methodology for organizing the educational process was also test at Kaunas University of Technology in January-July 2019, when a digital model of the historical center of the city of Kaunas created by a group of student architects under the guidance of university professors. Because of the development of the digital double with the support of business, government and representatives of Bentley Systems, a decision made to prolong this project and create an interdisciplinary center of smart cities and infrastructure at the Faculty of Architecture and Construction of KTU. Groups including students of different specializations within the educational process with modern didac- 
tics fill the information model with data for the Smart City project based on the cosmopolitan environment, innovative technologies (BIM, LEED), aimed at developing practical skills and teamwork in architecture and construction [8].

The training module implemented through the practice of project meetings, which simulates actual project meetings. Students of different faculties participating in the project form a project group in which each assigned a role (client, chief architect, design engineer and BIM coordinator).

The task of students is to design a building for a predetermined need by modeling BIM processes. In March - June 2018, Kaunas University of Technology (KTU), University College of Denmark (VIA) and the Norwegian University of Science and Technology (NTNU) conducted a SWOT analysis of the strengths and weaknesses of universities, as well as opportunities and threats from the external environment, and a survey for students of an architecture study program.

The purpose of the survey was to find out students' opinions about BIM. The survey involved 120 students, including 21 students from KTU (Lithuania), 19 from NTNU (Norway), and 80 from VIA (Denmark).

The survey showed that most students from these countries understand the importance of BIM, but it is not very popular among architectural companies, because the architectural environment is not sufficiently developing to implement this technology, since there are no special requests from clients [9].

In addition, the main disadvantages of universities were identifying lack of competencies and motivation, a fuzzy understanding of production needs. In the learning process, undergraduate students usually work with BIM technology for the exchange of information models (3D), but they do not cover the entire BIM process with all its relationships. In addition, most undergraduate students usually find work in the industry immediately after graduation and do not continue their studies in the magistracy, thus losing the opportunity to acquire information management skills, apply and understand BIM accordingly. Experience implementing BIM in KTU curriculum:

- 1-2 course - information-modeling skills go in parallel with general professional disciplines;

- 3 course - first BIM is introduced as a process, then BIM modeling skills go in parallel with professional disciplines;

- Course 4-5 - The BIM process is explain along with professional disciplines and BIM modeling.

It should be noted that the introduction of an interdisciplinary project training system in the curriculum of architectural and civil engineering universities is directly aimed at obtaining graduates not only in-depth theoretical knowledge in general professional and special disciplines, but, even more significant, in gaining practical experience in applying BIM technologies in the process of designing real objects.

Having examined the experience of introducing BIM-technologies into the learning process of several universities. We can conclude that by implementing practical and oriented interdisciplinary group work in the educational process of architectural and civil engineering universities, it is possible to increase the competitiveness of graduates 


\section{A. Masyonene}

of construction universities in the labor market in a short time, which will undoubtedly positively affect the development of the construction industry as a whole.

It should be noted that the introduction of a system of interdisciplinary design training in the educational program of architectural and civil engineering universities is directly aimed at obtaining graduates not only deep theoretical knowledge in general professional and special disciplines, but, more importantly., to gain practical experience in using BIM technologies in the process of designing real objects. It also proposed to recognize the competition cases completed in the course of study, protection as a group final qualifying work.

\section{Conclusions}

Thus, the practice-oriented method of introducing BIM technologies into the educational process at the senior courses of civil engineering departments is an actual technique that can really improve the quality of graduates of construction universities and their relevance in the labor market. In addition, such educational projects can have not only an educational orientation, but also social significance, if student groups are involved in solving important citywide problems of digitizing the historical centers of cities for the purpose of reconstruction and preservation of the architectural heritage.

\section{References}

1. The development strategy of the construction industry of the Russian Federation until 2030. PROJECT December 6, 2019 [Electronic resource]. M.: Ministry of Construction of Russia, 2019. URL: http://stroystrategy.ru/docs/ (accessed: 02.17.2020).

2. Volos I., Tereshchenko R.: To the question of the relevance of the introduction of information modeling of buildings in the educational process of training engineers // Science, technology and education. 2017. No. 10 (40). S. 100- 105. DOI: $10.20861 / 2312-8267-$ 2017-40-002.

3. Verbitsky A.: The quality of specialist training in contextual education // Actual issues of ensuring the quality of specialist training in professional educational organizations: Materials XVII All-Russian. Scientific-practical conf. Part 1. Voronezh: Voronezh College of Industrial and Humanities, 2016. C. 3-11.

4. Astashov A., Oshkina L.: The role of design information technology in the reform of engineering education // Education Integration. 2014. No. 4 (77). S. 116-123. DOI: 10.15507 / Inted.077.018.201404.116.

5. Bulavina D., Snezhkina O., Bochkareva O.: The implementation of intersubject communications in the educational process // Dnieper Scientific Bulletin. 2018. V. 6, No. 2. P. 1316.

6. Goldobina L., Orlov P.: BIM-technologies and the experience of their implementation in the educational process during the preparation of bachelors in the direction 08.03.01 "Construction" // Notes of the Mining Institute. 2017. V. 244.P. 263-272. DOI: 10.18454 / PMI.2017.2.263.

7. Semenov A.: BIM training at the university: necessary technologies // BIM modeling in the problems of construction and architecture: materials of the II Intern. Scientific and practical conf. SPb .: SPbGASU, 2019.S. 223-227. DOI: 10.23968 / BIMAC.2019.041. 
Practice-oriented Approach in Teaching BIM technologies... 7

8. Mlinkauskienė A., Jankauskaitė-Jurevičienė L., Christensen P., Finocchiaro L., Lobaccaro G.: BIM Integration Possibilities in Different Study Cycles of Architecture Study Program // ADVANCED CONSTRUCTION 2018. Proceedings of sixth International Scientific Conference. P. 24-25.

9. Šadauskienė J., Pupeikis D.: Review of BIM Implementation in Higher Education // Journal of Sustainable Architecture and Civil Engineering. 2018. Vol. 22, No. 1.Author, F.: Article title. Journal 2(5), 99-110 (2016). 